\title{
Wayang Tengul Art Performance: A Study of People's Appreciation of Wayang Tengul Art
}

\author{
Tutung Nurdiyana ${ }^{\bowtie}$ \\ Department of Performing Art, Faculty of Teaching and Education Science, \\ Universitas Lambung Mangkurat, Indonesia
}

Submitted: September 16, 2019. Revised: November 4, 2019. Accepted: December 28, 2019

\begin{abstract}
Wayang tengul is one type of wayang (puppet) belonging to Indonesia existing in Sidobandung Village, Balen Subdistrict, Bojonegoro Regency. This wayang is still preserved and found attractive by society until now. This wayang preservation depends on society's appreciation as the audience of wayang tengul and is one of the most important factors for the success of a performance. Therefore, this research attempts to describe how people in Sidobandung Village appreciate wayang tengul. This qualitative research was conducted in Sidobandung Village. It shows how the people highly appreciate wayang tengul art since this wayang art is unique, not strictly bound by wayang common practice, performed interactively between dalang (puppeteer), gending (Javanese music) and audience and laden with guidance presented in fresh jokes.
\end{abstract}

Keywords: Wayang Tengul; Appreciation; Audience

How to Cite: Nurdiyana, T. (2019). Wayang Tengul Art Performance: A Study of People's Appreciation of Wayang Tengul Art. Harmonia: Journal of Arts Research And Education, 19(2), 163-171.

\section{INTRODUCTION}

Wayang is one cultural heritage that survives, especially in Javanese society, and also the national pride in art. Wayang is called an adiluhung (high quality) art, since it is an artwork which is laden with philosophical, symbolic and historical values of ancestral heritage, which needs be preserved (Harsojo, 1998).

There are various forms and types of wayang in Indonesia, one main form of which is wayang kulit, which has been taking a special place in the heart of the Indonesians for centuries, both elites and common folks. Wayang kulit is a traditional art with great number of fans, while it has existed for hundreds of years, but survives changing times.
Some state that wayang, especially wayang kulit, is a depiction of Javanese culture and a manifestation of Javanese people's cipta, rasa and karsa in every aspect of society and state life. Wayang is familiar to Javanese people and contains many interesting things for entertainment while serving as a medium of communication and education which remains relevant in every era, since wayang is dynamic and able to keep up with development in the society. According to Clifford Geertz, when a person desires to study Javanese culture, he/she should start from understanding and learning wayang (Bastomi, 1993). The reason is that wayang summarizes the Javanese people's views of life. The Clifford Geertz's opinion is quite understandable since art is an expression

\footnotetext{
Corresponding author:

E-mail: tutung.nurdiyana@gmail.com
} 
generated from existing ideas, values and norms in the mind of individuals in the society. Meanwhile, according to Mulyono, wayang's high quality may be found in multiple values, including entertainment value, art value, education value, scientific and spiritual enlightenment, and religious value (Mulyono, 1979).

Wayang performance in a traditional agricultural society is often intended to be teaching. Besides the most important part of religious ceremony, wayang performance is filled with various teachings of life, from philosophy to moral teaching for rural farmers. This shows that wayang performance has currently become an important part of the society's socio-cultural system. However, in industrial or urban society, especially transitional society, wayang performance has transformed its functions and roles. Wayang in such societies often serves as entertainment, ethnical identity and social class stratification in Javanese society, cultural commodity and a little still serving as a small part of a description of the meaning of life of a group of Javanese society. In this context, wayang is understood as an aspect of teaching and pitutur (advice) instead of as the main essence, but the aspects of entertainment commodity, technical skill to generate new creation and artistic aspect instead.

The current wayang kulit is human's work which has been continuously worked on and improved for centuries from generation to generation. Various cultures influence the form and philosophy of wayang, from original ancestral culture, Hinduism, Buddhism to Islam. With the arrival of Islam, the history of wayang art in Indonesia developed in every aspect of Indonesian-Islamic visual art tradition. At that time, a form of wayang was born, which reflected a more appropriately mature conception to the Indonesian art tradquated ition, visually and spiritually.

In the past, when Islam entered Java island, the role of wayang as a medium of dakwah was very useful since through wayang performance, Islamic teaching was inserted. The Muslim missionaries (mubaligh
- walisongo) used wayang as a medium of dakwah which could not be separated from the idea that wayang was already familiar to Javanese people, thus for ease of dissemination of Islamic teaching and people's acceptance of it, wayang was used. According to Mulyono (as quoted by Amir, 1994), the Islamic teaching introduced by the wali includes the Javanese version of wayang genealogy, that according to this genealogy, wayang started from one ancestry, that is Prophet Adam.

The wali who disseminated Islam in Java Island, besides creating wayang genealogy which was connected with Islamic teaching, often created gendhing-gendhing and wayang story for dakwah purpose. With regard to these activities, there is an assumption in the society that the ones who created wayang, gamelan and pakem-pakem pedalangan are the wali at the time Islam started developing. This assumption, according to Pigeaud (Wibisono, 1991), is believed by the people on the north coast of Java. Besides, wayang performance, which was deemed sacred during the pre-Islamic era, was popularized by the wali, rearranged and adjusted to Islamic teaching and the cultural value system of its supporting society. This Pigeaud's opinion is in line with Amir's statement, that for dissemination and development of Islam, the pantheist goods system in wayang performance with its hierarchical divinity system was modified, putting gods as the executors of God and not other than God (Amir, 1994).

Now, wayang serves a function and role in society's cultural life. The function and role of wayang since its creation and in its journey are not fixed depending on the need, demand and working of its supporting society (Wibisono, 1991). Javanese culture, which supports the existence of wayang, is changing. Therefore, it is impossible to maintain and preserve a cultural element while its supporting society has been and is continuously changing. Therefore, what we need to do is changing, revising and modifying wayang in order for it to survive in the society's changing culture (Waluyo, 2000). 
In Bojonegoro, there is a type of wayang called 'wayang tengul' with some uniqueness. First, wayang tengul has no standard like the standard pakem pedalangan wayang kulit. Therefore, the way to present it is up to the dalang. Although the story has certain guideline, but the version of the story is up to the dalang. Second, nayogo (gamelan players) and sinden (singers) are involved in dialogue with dalang, talking in a bi-directional conversation, thus humorous comments are commonly used in about 8 hours of wayang tengul performance. Such bi-directional dialogue does not bore the audience. Some audiences also occasionally make humorous comments, from which dalang makes jokes.

In addition to its uniqueness, wayang tengul also has its characteristic of using typical Bojonegoro dialect called Javanese language Ngukuh. The purpose dalang of wayang tengul use typical Bojonegoro dialect is for wayang tengul art to have an impression and nuance of original art performance of Bojonegoro society and also to stimulate the audience in each performance, so that they will not get bored listening to standard Javanese language Kromo Inggil.

The uniqueness and typicality of wayang tengul remain showing the simplicity of performance as a cheap show to entertain the society since the rate for each wayang tengul performance is also far lower than that of wayang kulit performance. The rate of each performance is based on the story to be told and its duration, since the duration of wayang tengul performance may be shortened at request of the host. Wayang tengul, as a traditional art that is still loved by Bojonegoro people, actually still serves function like the other existing traditional arts such as oklik, tayub and sandur. The reason is that wayang tengul contains various arts such as dance art, music art, pedalangan at, visual art and performing art.

This wayang tengul art is still preserved until now, particularly in Sidobandung Village, Balen Subdistrict, Bojonegoro Regency, which is the location where the research on wayang tengul is conducted. In this village, wayang tengul still exists and is preserved for generations as an ancestral heritage, as proven with many and frequent wayang tengul performances held in the society in certain events. Wayang tengul performance is commonly held in relation to people's social activities. For example, a change of government official event, governmental events from village to regency levels, marriage, birth, circumcision or any event related to a person's life cycle ceremony or in other ceremonies deemed important by the society.

Based on the existence of wayang tengul which remains preserved by the people in Sidobandung Village and of the audiences who are still fond of and loyal to it from various groups, the researcher is interested to study wayang tengul audience's appreciation. Wayang tengul audience is one of the most important factors for the success of its performance. This audience is derived from various groups, including children, youths and elders. In every wayang tengul performance, the audience or each individual appreciates what the performance they watch differently. The audience also has their respective purpose of choosing which dalang is appropriate to perform a certain story in wayang tengul performance and they have the criteria for it. Dalang of wayang tengul must, if not want to be left by his audience, strive for making his performance attractive. Not only by developing how to perform, but the story is occasionally made not pursuant to the standard. However, a dalang must be aware of wayang genealogy.

Sidobandung people's appreciation of wayang tengul art performance becomes the research's focus. People's appreciation of or response to traditional art in this modern era is then important as why they still desire to pay attention to traditional art, especially wayang tengul. Based on the background above, the research attempts to answer the problem, of how is people's appreciation of Wayang Tengul in Sidobandung Village? 


\section{METHOD}

This qualitative research focused on items in their natural context, attempting to understand, or interpret, phenomena from the perspective of meaning attached by human (researcher) to it (Denzin, et al., 2009).

The qualitative research employed here was ethnography. According to Spradley, ethnography is a work to describe culture. The purpose of this activity was to understand a view of life from the perspective of native inhabitants. Furthermore, Spradley states that the essence of ethnography is the effort to pay attention to the meaning of action from an occurrence happening to the person we want to get an understanding of. Some of these meanings are directly expressed in language, and many are received and conveyed only indirectly through words and actions (Spradley, 1997).

Qualitative ethnographic research in social research may also be employed to study certain issues to be taken as the theme, thus it does not have to describe the culture of a certain society holistically. This view is stated by Hammersley and Atkinson regarding ethnography. According to Hammersley and Atkinson, "ethnography" is a method with typicality. Ethnography consists of some research activities in the form of ethnographer's participation in daily life within a long period, seeing what happens, listening to what they say, asking a question. In short, ethnography means collecting any data which may be used to understand issues which becomes the research focus (Hammersley, et al., 1995).

This research employed ethnography, aiming at describing the wayang tengul phenomena more thoroughly and emphasizing exploration attempt on the Wayang tengul phenomena through a set of non-structured data in the society's version, to be analyzed interpretatively to generate an overview of the society's appreciation of performing art wayang tengul more comprehensively.
Through informants, interview aimed at collecting information and data from certain individuals. In this regard, to enter into the society on which the study was conducted, the researcher needed purposively determined informants. The research informants included dalang who was deemed to have extensive knowledge of wayang. In addition to dalang, the other informant was wayang tengul maker or craftsman. This informant was deemed to have actual understanding of characters inherent in wayang tengul dolls they made.

The researcher obtained the appreciation data from various wayang tengul fans and audiences as informants. The audience of wayang tengul art performance was gathered accidentally when a performance was in progress, and the fans were not only obtained during the performance, but visited in their home. There are 13 informants from which information of their appreciation of wayang tengul art performance is collected, consisting of 2 (two) children (8-10 years old), 2 (two) adolescents/adults (15-40 years old), and 9 (nine) elders (41-60 years old).

After the research had been conducted and data were collected completely from the field, the next phase was analysis. In this phase, the data were used in such a way for answers to the research problems. Furthermore, the analyzed data were interpreted using the concept and theory presented in the frame of reference, thus a complete overview was obtained for the research focus. Finally, of all that have been conducted, a conclusion of the research problem was made.

\section{RESULT AND DISCUSSION}

\section{History of the Origin of Wayang Tengul in Sidobandung Village}

It was relatively difficult to collect the data of wayang tengul history since there was no written evidence of the origin of wayang tengul. The researcher eventually obtained the data of the origin of wayang tengul based on folklore which was deemed to be the actual history of the origin 
of wayang tengul by the people in Sidobandung Village. The folklore is as follows:

In the past, wayang tengul was initially a child game in the village after they had finished herding their livestock and coming home from farm work, in the form of wooden doll game made by themselves and played on the table. The doll's head and body were made separate, thus the doll was movable. The doll's head may be moved rightward-leftward, upward and even rotating. People say the head was able to tungal-tungul (head movement to any direction), thus it is called 'wayang tengul.' The doll took arbitrary form and the story was up to the doll player. The music was played with surrounding items which were just hit as the players pleased. Over time, this doll game was deemed interesting and entertaining to those who watched, thus the people developed it into wayang tengul art performance. The form of doll, story, performance stage, and gamelan were made in such a way, belonging to the people of Sidobandung Village.

That is the story developing among the people in Sidobandung Village of the origin of wayang tengul. The story of the origin of wayang tengul, as told by Kayam (Kayam, 1981) is that the concerned society will claim society as a union of humans and what we call society's creativity is originated from its supporting people, as well as what we call folk art, folk song, and folk dance of which creators are unknown (even if they started from creators who were members of the society) as theirs.

The people of Sidobandung Village have never known who created or started wayang tengul art for sure. The knowledge of people of Sidobandung Village of wayang tengul is from folklore developing through word of mouth from generation to generation, thus wayang tengul is known as the traditional art of Sidobandung society. According to Harsojo (1998), the characteristics of folk art is that the values contained in that folk art are the reflection of the way of daily life of the concerned society or derived from myth developing in the society.

\section{Time and Place of Wayang Tengul Perfor- mance}

Wayang tengul performance in Sidobandung Village is held at certain times deemed important or special, such as wedding party, circumcision, and bersih desa events. For people's ceremonial event, it is commonly held in certain months believed by Javanese people as good months to bring luck.

The time of wayang tengul performance is mostly at night, but some are also held in daytime, commonly at bersih desa or ceremonial events depending on the request and agreement between the host and dalang, since there is basically no restriction for a wayang tengul performance in daytime. In daytime performance, lamps are not used, that it is bright, no shadow of wayang is generated.

The place for wayang tengul performance may be everywhere, such as village office, sports field, or yard of individual who has ceremonial event. In case the yard is too small, the alternative is to put a stage for performance on the road in front of one's house, by first getting permission from village authority. The reason to choose wide space is for the guests or audience to watch wayang tengul performance conveniently.

\section{Wayang Tengul Story}

Wayang is a performing art which displays dolls made of leather or wooden resembling human. Wayang, which is an inanimate or mute object, will live and speak when it is involved in a story brought by dalang. Therefore, it is dalang who actually preaches wewayanganing ngaurip or reflection of life, giving example to people. The stories played in wayang tengul are those related to the history of Islam derived from Serat Menak, Babad Tanah Jawi, and Majapahit referring to East Java style pedalangan story.

The East Java standard structure is free, which means that it does not have to follow a mainstream sequence. In Central Java pedalangan standard, after jejer scene is kedaton scene, followed with outer pase- 
ban and dodolan, but East Java standard is arbitrary according to the story. The same is with wayang tengul, the scenes in this wayang performance are not structured according to the standard since it does not have one. The sequence of the story is also up to dalang but there is jejer as guideline for dalang. Gamelan in wayang tengul is laras slendro.

Stories in wayang tengul are mostly in the form of carangan made by dalang which are occasionally derived from folklore. The stories are usually mild, which means that they do not contain deep story like history or genealogy of wayang. The humor element is dominant, intending to attract and stimulate the audience. Behind that, however, wayang tengul is laden with Islamic teaching which emerges in the middle of the scene that it has been prepared. The Islamic teaching is commonly delivered during Umar and Amir (characters) scene (menak history). This Islamic teaching is delivered in addition to the existing story and is connected with current occurrences, thus the scene is focused on religious content.

Below is the general composition or sequence of story in wayang tengul as well as examples of story to perform: A performance with the theme "Menak History Umar Amir":

\section{Jejer I}

There is a kingdom named Merdayin with its king called Nursewan, having a disaster of the existence of a giant or buto named Buron Amru residing in Payal forest who eats human. This puts king Nursewan to restlessness, until he makes a sayembara (competition), that whoever kills Buron Amru will be given with the kingdom and the throne as well as princess Dewi Muninggarsari.

\section{Jejer II}

There is a war between Buron Amru and imperial soldiers in Payal forest, leading to the defeat of the kingdom Merdayin.

\section{Jejer III}

Umar and Amir sons of Abdul Muntalib, in their journey, hear of the sayembara and intend to participate in the sayembara. Finally, Umar and Amir are able to kill Buron Amru. However, when they arrive at the palace of kingdom Merdayin, they still have to pass one more test since, as king Nursewan says, becoming a king is not something easy, they have to conquer a thousand kingdoms, including King Lamdaur from mount Srandil, King Maktal, King Jemblung Marmadi, King Tamtanus Swantanus from Selomiring, and many others.

\section{Jejer IV}

Umar and Amir finally get separated, while Amir successfully conquers a thousand kingdoms and meets a supernaturally strong person, His Excellency Kelir, and is given with heirlooms Cemeti Jabarnas and Kuda Kalisaha.

\section{Jejer $\mathbf{V}$}

Umar meets Prophet Daud and is given with an heirloom Kasang Kasud Kudratullah and eats wood Kistabul Jati in Swargo Ungkul. The function is that he will be invulnerable to any highly toxic venom. In the end, Umar and Amir meet and return to Kingdom Merdayin to be enthroned by King Nursewan. Amir is given with the throne and married to Dewi Muninggar Sari. Amir's kingdom is called Kingdom Puser Bumi or Mekkay and has his name changed to Sang Agung Jayengrono Dimukti. Umar is given with a throne as regent in Talkandangan regency and married to Dewi Bastari. Umar has his name changed to Utet Umar Maya.

\section{Audience of Wayang Tengul Performance} Wayang tengul is one of art performances with so many fans in Sidobandung Village. This may be seen from how often the people have wayang tengul performance for their certain ceremonial event, both individual and joint events. Besides the high frequency of people having wayang performance, this may also be seen from 
the abundant number of audiences every time a wayang tengul performance is held.

The audience of wayang tengul is one of the most important factors for the success of its performance. Even if a performance is very good, when there is no audience, it will be meaningless. The audience of wayang tengul in Sidobandung Village consists of various groups. According to Waluyo, the audience of wayang consists of children, youths, and elders, both male and female (Waluyo, 2000). The audience of wayang tengul is not limited only to the people of Sidobandung Village, but also from surrounding villages, such as Sidodadi Village, Mayangkawis Village, and Duyungan Village.

Wayang tengul is an entertainment mostly watched by children, that its form of storytelling is particularly attractive to them. In a year, they averagely watch wayang tengul 8-10 times. Often, they even unconsciously fall asleep about the stage while watching the performance. Differently from elders and youths, children usually arrive at wayang tengul performance early in the beginning. Just like children in general, they prefer watching fight scene and humor scene by limbuk and cangik.

Most of the audiences are youths. This group ranges from 15-40 years old. Differently from children group, 15-year old audience is able to assess how proficient dalang is. This youth group tends to prefer crowd, beauty, and humor. However, some of them fathom the philosophy of wayang tengul. Therefore, young audience prefers dalang who are proficient in antawacana or conversation, sabetan or technique to play wayang, and mbanyol or joking.

Old audience, 41 years old and above, has their own choice to watch wayang tengul performance, slightly different from that of young audience. Although this group of audience has watched the same story repeatedly, but they do not find it boring to watch. When they are asked to tell the whole performance, they memorize it well. This old group of audience often contemplates the teachings delivered by dalang through the story of wayang tengul performance. Therefore, this old audience is commonly serious at scenes which display very important dialogue which need wise problem solving.

The audience watches the performance from the seats prepared 4-6 meters away from the screen. These seats are commonly prepared for guests. Meanwhile, they who just want to watch the performance but without invitation from the host may watch the performance from afar or wherever they feel convenient.

As the researcher finds, the number of audience of wayang tengul performance after late at night will decline because of tiredness and drowsiness, particularly child audiences and some youth audiences. For elder audiences, even if their physical condition is poor, most of them watch until the end of performance. However, in every wayang tengul performance, not less than 50 audiences watch it until the end. The researcher even once found an audience who was getting really drowsy (repeatedly yawning) was not willing to leave and waited the wayang story told by the dalang to end. Such an audience is the big fan of wayang tengul performance, that he will feel at a big loss when they cannot watch the performance until the end.

\section{Society's Appreciation of Wayang Tengul Wayang tengul performance in Sido-} bandung Village seems to have made a certain impression and value for the people of Sidobandung Village until now, thus many of them are fans of it. As society's work, wayang tengul is dynamic, as shown with its capability to attract people of Sidobandang Village until now. This is in line with Akhyanto's statement, that wayang as a traditional art is dynamic with its capability to pass through space and time, much of which is influenced by dalang as the main actor in wayang art (Akhyanto, 1988).

One of the reasons for the people to love wayang tengul is a factor of habit, that they have watched wayang tengul from childhood to old age, thus they are socialized with and love wayang tengul. This reason is expressed by an informant named 
Mufid (50 years old):

"Wiwit alit kulo ngantor sepuh, kulo asring sanget ningali wayang tengul, amargi ing Deso Sidobandung kathah ingkang nanggap wayang niki. Dadose dangu-dangu kulo inggih remen kalian wayang tengul."

(From childhood until old age, I have often watched wayang tengul, since this wayang is often performed in Sidobandung Village, thus as time passes I get to love wayang tengul).

Another reason is presented by informants named H. Gunawan (48 years) and Surif (53 years old). They love wayang tengul since they believe in the story and Islamic teaching it contains wayang tengul. The reason is:

"Kulo remen kalian ringgit tengul punika amargi kulo remen lakoniopun, biasanipun ringgit tengul puniko disisipi kalian dakwah Islam. Dadose pesenpesen ingkang wonten ringgit tengul ponika saget ditiru gae kalian para tiang ingkan g ningali ringgit punika."

(I like wayang tengul since I like its story. Wayang tengul story is usually inserted with Islamic teaching, thus the messages it contains may be taken as example for its audiences).

A teenager named Yudi (19 years old) presents a different reason regarding wayang tengul. He loves and often watches wayang tengul since the story in wayang tengul is not monotonous like that in wayang kulit that tells the story of Ramayana and Mahabharata. Its story varies and its language is informal, and it has more humor element. The following statement is made by Yudi:

"In my opinion, wayang tengul is a nonboring wayang show that it story varies and its languages may be understood by every person, young or old, and its humor element refreshes the audience."

There are many reasons presented by the informants of wayang tengul, but the next one is an informant who had once hired a dalang to perform wayang tengul. Ansari (58 years old), this informant loves wayang tengul since it is a Javanese folk art, especially Indonesia's cultural art. Therefore, in his daughter's marriage, he had a wayang tengul performance in consideration that wayang tengul is an interesting folk show for a low rate. Below is Ansyarai's comment:

"I had wayang tengul performance since I like this original Javanese art, and its rate is affordable. This entertainment may be enjoyed by me, my family, and also neighbors. Thus it entertains many people."

The audience's excitement and satisfaction are relative, which means that each person has different level of excitement and satisfaction since they have their own taste.

Wayang tengul, according to an informant named Abdullah (45 yeas old), is not the same with any other wayang, since this wayang is not boring. As evidence, many children in Sidobandung Village love it. In each performance, many children come to watch. Below is Abdullah's statement:

"Wayang tengul is entertainment with its distinguished attractiveness and uniqueness compared to any other wayang. Its story is good (with Islamic nuance), dalang and nayogo participate interactively in dialogue, making fresh humor, and its rate is affordable."

Generally, children love joke and fight scenes. After watching wayang tengul performance, they often imitate dalang's funny words and wayang's fighting style presented. The following is the comment of a child named Sidin, 10 years old while waching wayang tengul:

"Wayang tengul dolls have funny shapes, some are fat, some are thin, and its story is also funny. I like the fat doll of wayang tengul named Limbuk the most. When the dalang starts putting out the dolls from the box, all of my friends will certainly compete for the foremost seat."

Siti, 12 years old, makes different statement from Sidin. She love fight scene the most. The following is her statement:

"The tensest part is when the protago- 
nist is fighting buto ijo. The protagonist is small and Buto Ijonya is big, but the small protagonist wins."

Children's opinion of wayang tengul is different from youths' and elders' opinion. They are simple and what they talk is only about doll playing and how funny the dalang is.

\section{CONCLUSION}

Wayang tengul art performance in Sidobandung Village is still found attractive by the people, not only since this performing art is originated from local village, but they truly love this art performance. The young generation automatically inherits this art tradition willingly without any coercion.

The people Sidobandung appreciate wayang tengul art performance very well and enthusiastically, as proven with so many audiences from various groups, constituting children, adolescents and elders, in each of its performance. The people appreciate this art differently by age. Children love this art performance for the humor brought by dalang in playing funny characters and for fight scene. Adolescents and adults love the non-boring excitement of wayang tengul made by dalang, sinden and gamelan. Meanwhile, elders love wayang tengul art performance for the essence of wayang tengul story with the story of Is- lam history and wayang stories made differently from any other wayang.

\section{REFERENCES}

Akhyanto, A. (1988). Perspektif Wayang Dalam Pertumbuhan Kebudayaan Nasional. Cakrawala Pendidikan, 1(1), 93-100.

Amir, H. (1994). Nilai-nilai Etis Dalam Wayang. Jakarta: Pustaka Sinar Harapan.

Bastomi, S. (1993). Nilai-nilai Seni Pewayangan. Bandung: Dahara Press.

Denzin, N. (2009). Handbook of Qualitatif Research, Translated by Dariyatno, $d k k$, Jakarta: Pustaka Pelajar.

Hammersley, M. \& Atkinson, P. (1995). Ethnograpy: Principles in Practise. UK: Routledge.

Harsojo, S. (1998). Pratiwimba Adiluhung, Sejarah dan Perkembangan Wayang. Jakarta: Djambatan.

Kayam, U. (1981). Seni, Tradisi, Masyarakat. Yogyakarta: Sinar Harapan.

Mulyono, S. (1979). Simbolisme dan Mistikisme Dalam Wayang. Jakarta: Gunung Agung.

Spradley, J. P. (1997). Metode Etnografi, Yogyakarta: PT Tiara Wacana Yogya.

Waluyo, K. (2000). Dunia Wayang: Nilai, Estetis, Sakralis, dan Ajaran Hidup. Semarang: Pustaka Pelajar.

Wibisono, S. (1991). Wayang Sebagai Sarana Komunikasi. Jakarta: Gramedia Pustaka. 